\title{
Publisher Correction: A general and flexible method for signal extraction from single-cell RNA-seq data
}

\author{
Davide Risso (1D 1, Fanny Perraudeau ${ }^{2}$, Svetlana Gribkova ${ }^{3}$, Sandrine Dudoit ${ }^{2,4}$ \& Jean-Philippe Vert (D) $5,6,7,8$
}

Correction to: Nature Communications https://doi.org/10.1038/s41467-017-02554-5, published online 18 Jan 2018.

The original PDF version of this Article contained errors in two equations. In equation 1, all $\Gamma$ symbols were inadvertently omitted. In the second equation in the subsection entitled '1. Dispersion optimization' within the Methods section 'ZINB-WaVE estimation procedure', all $\Psi$ symbols were inadvertently omitted. These errors have been corrected in the PDF version of the Article; the HTML version was correct from the time of publication.

Published online: 04 February 2019

(c) Open Access This article is licensed under a Creative Commons Attribution 4.0 International License, which permits use, sharing, adaptation, distribution and reproduction in any medium or format, as long as you give appropriate credit to the original author(s) and the source, provide a link to the Creative Commons license, and indicate if changes were made. The images or other third party material in this article are included in the article's Creative Commons license, unless indicated otherwise in a credit line to the material. If material is not included in the article's Creative Commons license and your intended use is not permitted by statutory regulation or exceeds the permitted use, you will need to obtain permission directly from the copyright holder. To view a copy of this license, visit http://creativecommons.org/licenses/by/4.0/.

(C) The Author(s) 2019

\footnotetext{
${ }^{1}$ Division of Biostatistics and Epidemiology, Department of Healthcare Policy and Research, Weill Cornell Medicine, New York, NY 10065, USA. ${ }^{2}$ Division of Biostatistics, School of Public Health, University of California, Berkeley, CA 94720, USA. ${ }^{3}$ Laboratoire de Probabilités et Modèles Aléatoires, Université Paris Diderot, 75005 Paris, France. ${ }^{4}$ Department of Statistics, University of California, Berkeley, CA 94720, USA. ${ }^{5}$ CBIO-Centre for Computational Biology, MINES ParisTech, PSL Research University, 75006 Paris, France. ${ }^{6}$ Institut Curie, 75005 Paris, France. ${ }^{7}$ INSERM U900, 75005 Paris, France. ${ }^{8}$ Department of Mathematics and Applications, Ecole Normale Supérieure, 75005 Paris, France. Correspondence and requests for materials should be addressed to S.D. (email: sandrine@stat.berkeley.edu) or to J.-P.V. (email: jean-philippe.vert@ens.fr)
} 